\title{
Pengaruh Kinerja Lingkungan Dan Kinerja Keuangan Teradap Pengungkapan Informasi Lingkungan
}

\author{
Nur Chanifah $^{1 *}$, Husnah Nur Laela Ermaya ${ }^{2}$, Ayunita Ajengtyas Saputri Mashuri ${ }^{3}$ \\ ${ }^{1,2,3}$ Fakultas Ekonomi dan Bisnis Universitas Pembangunan Nasional Veteran Jakarta, \\ Jalan RS. Fatmawati No. 1, Pondok Labu, Jakarta Selatan \\ ${ }^{1}$ nurchanifah298@gmail.com
}

\begin{abstract}
This research is using quantitive study aimed to see whether there are influence of environmental performance and financial performance on environmental disclosure. This study uses non-financial companies listed on the Indonesia Stock Exchange as a population. Sample selected by purposive sampling and collected 20 non-financial companies, with a research period of 2015 2017, but for the measurement of financial performance, the data taken was data for 2014-2016, because in this study, tested is the effect of financial performance in the previous year on disclosure of environmental information in the current year. Testing the hypothesis in this study uses Multiple Linear Regression Analysis with SPSS version 25 and a significance level of 5\% (0.05). The results of this study indicate that: (1) environmental performance has a significant positive effect on environmental disclosure, (2) financial performance in the previous year has a significant negative effect on environmental disclosure in the current year. The variables of environmental performance and financial performance can explain the environmental disclosure variable of $26,4 \%$.

Keywords : Environmental Disclosure, Environmental Performance, Financial Performance
\end{abstract}

\section{PENDAHULUAN}

Pada era globalisasi saat ini, isu lingkungan menjadi suatu masalah penting yang perlu diperhatikan. Hal tersebut tentunya menimbulkan berbagai tuntutan bagi perusahaan untuk lebih memperhatikan tanggung jawabnya atas keadaan lingkungan \& masyarakat sekitar. Bentuk pertanggungjawaban tersebut dapat dilakukan dengan memberikan informasi yang transparan di dalam laporan tahunan perusahaan mengenai aktivitas lingkungannya kepada masyarakat, dikarenakan masyarakat membutuhkan informasi mengenai sejauh mana perusahaan sudah melaksanakan aktivitas sosialnya sehingga hak masyarakat untuk hidup aman dan tentram, serta keamanan dalam mengkonsumsi makanan dapat terpenuhi (Anggraini, 2006).

Sehubungan dengan hal tersebut, maka saat ini perusahaan tidak lagi hanya memperhatikan catatan atau laporan yang terkait dengan informasi keuangan saja (Single Bottom Line), melainkan juga harus memperhatikan aspek sosial dan lingkungan sekitarnya (Triple Bottom Line). Dengan adanya bentuk pertanggungjawaban tersebut, akan membuat masyarakat tidak lagi merasa dirugikan oleh dampak dari kegiatan operasional perusahaan, sedangkan bagi perusahaan sendiri, dengan adanya Environmental Disclosure yang baik, perusahaan akan memperoleh manfaat positif berupa perhatian, kepercayaan, dan dukungan dari masyarakat (Zulfikar dkk., 2016).

Di Indonesia sendiri, pemerintah telah mengatur tentang kewajiban perusahaan atas tanggung jawab sosial dan lingkungannya melalui UU RI Nomor 40 Tahun 2007 Pasal 74 Tentang Tanggung Jawab Sosial Dan Lingkungan, dalam undang-undang tersebut disebutkan bahwa 'Perseroan yang menjalankan kegiatan usahanya di bidang dan/atau berkaitan dengan sumber daya alam wajib melaksanakan Tanggung Jawab Sosial dan Lingkungan'.

Berbagai kasus pencemaran lingkungan yang diakibatkan oleh aktivitas perusahaan masih banyak terjadi di Indonesia. Di antaranya adalah kasus pencemaran lingkungan yang terjadi di Perairan Pulau GAG, pencemaran yang diakibatkan oleh limbah tambang nikel PT GAG anak perusahaan PT Antam Tbk ini 
membuat Perairan Pulau GAG menjadi berwarna coklat (Sindonews, 2018). Selain itu, pencemaran lingkungan juga terjadi di Desa Karanglo, Kabupaten Tuban, yang merupakan desa yang terletak di ring satu kawasan pertambangan milik PT. Semen Indonesia Tbk . Wahana Lingkungan Hidup Indonesia (Walhi) Jawa Timur menduga, aktivitas pertambangan semen di Tuban tersebut menjadi penyebab utama kematian beruntun warga di kawasan itu, kematian tersebut dikarenakan pencemaran udara di sekitar kawasan tambang semen cukup tinggi. Selain pencemaran udara, pencemaran air juga sudah dirasakan oleh masyarakat, seperti perubahan kondisi air sumur milik warga yang menjadi asin (Mongabay, 2016). Kasus selanjutnya, Greenpeace Indonesia merilis hasil investigasi terkait aktivitas pertambangan batubara oleh PT Indominco Mandiri, anak perusahaan PT Indo Tambangraya Megah Tbk. di Provinsi Kalimantan Timur yang merusak bentang alam dan mengganggu kualitas air tanah. Lahan yang semulanya merupakan hutan dan lahan pangan menjadi danau-danau bekas tambang yang terbengkalai dan tanah gersang, sehingga masyarakat mengeluhkan kelangkaan air (greeners, 2016).

Kementerian Negara Lingkungan Hidup memiliki Program Penilaian Peringkat Kinerja Perusahaan (PROPER) sebagai salah satu upaya untuk mendorong penaatan perusahaan dalam pengelolaan lingkungan hidup. Melalui PROPER tersebut, kinerja lingkungan perusahaan dapat dinilai berdasarkan peringkat warna emas, hijau, biru, merah, hingga hitam yang diperoleh perusahaan.

Di samping melakukan tanggung jawab sosial dan lingkungannya kepada masyarakat, perusahaan juga harus memenuhi tanggung jawabnya kepada para pemegang saham, yaitu dengan meningkatkan kinerja keuangan perusahaan. Baik atau buruknya kinerja keuangan perusahaan dapat dinilai dari laporan keuangan yang dikeluarkan oleh perusahaan secara periodik. Kinerja keuangan perusahaan tersebut juga akan digunakan sebagai salah satu dasar pengambilan keputusan, baik oleh pihak internal maupun eksternal.

Beberapa penelitian empiris sebelumnya mengenai pengungkapan informasi lingkungan yang dikaitkan dengan kinerja lingkungan dan kinerja keuangan perusahaan, masih menunjukkan hasil yang berbeda-beda. Sebagaimana penelitian yang dilakukan oleh Rahardja dan Pratama (2013) pada perusahaan manufaktur dan tambang yang terdaftar pada Bursa Efek Indonesia (BEI) dan termasuk dalam PROPER tahun 20092011, membuktikan bahwa kinerja lingkungan memiliki pengaruh terhadap pengungkapan informasi lingkungan. Penelitian tersebut memiliki hasil yang sama dengan penelitian yang dilakukan oleh Deswanto dan Siregar (2017) yang meneliti mengenai hubungan antara pengungkapan lingkungan dengan kinerja keuangan, kinerja lingkungan, dan nilai perusahaan. Namun hasil penelitian yang dilakukan oleh Wijaya (2012) yang menguji pengaruh faktor-faktor yang mempengaruhi pengungkapan tanggung jawab sosial pada perusahaan manufaktur yang terdaftar di bursa efek indonesia, menunjukkan hasil yang berbeda, yaitu tidak adanya pengaruh yang signifikan antara kinerja lingkungan terhadap pengungkapan tanggung jawab sosial perusahaan.

Warotikan dkk. (2015), melakukan penelitian mengenai pengaruh ukuran perusahaan, ROA dan DER terhadap pengungkapan tanggung jawab sosial perusahaan, di mana hasil yang diperoleh dari penelitian tersebut yaitu terdapat pengaruh yang signifikan antara kinerja keuangan yang diukur menggunakan Return on Asset (ROA) terhadap pengungkapan tanggung jawab sosial perusahaan. Namun, penelitian yang dilakukan oleh Kamil dan Herusetya (2012) dan Deswanto dan Siregar (2017) menemukan hasil yang berbeda, di mana kinerja keuangan yang diukur 
menggunakan profitabilitas tidak memililiki pengaruh terhadap pengungkapan informasi lingkungan.

\section{KAJIAN PUSTAKA \\ Teori Stakeholder}

Freeman (1983) menyatakan bahwa istilah stakeholder pertama kali diperkenalkan oleh Stanford Research Institute untuk menjelaskan "suatu kelompok yang tanpa dukungannya, organisasi akan berhenti" (those groups without whose support the organization would cease to exist). Teori stakeholder digunakan sebagai dasar untuk menganalisis kepada siapa perusahaan harus bertanggung jawab. Teori stakeholder menyatakan bahwa, untuk mempertahankan eksistensinya, perusahaan membutuhkan dukungan dari para pemangku kepentingan, sehingga aktivitas perusahaan juga harus mempertimbangkan persetujuan dari para stakeholder (Gray et al., 1995). Stakeholders merupakan individu atau entitas yang memiliki kepentingan baik dalam kepentingan ekonomis maupun non ekonomis dari perusahaan.

Berdasarkan pada pernyataan di atas, peran dari stakeholders sangatlah penting, karena berkaitan dengan kelangsungan hidup perusahaan secara berkelanjutan. Dengan adanya pernyataan-pernyataan tersebut, maka anggapan bahwa keberhasilan perusahaan semata-mata hanya bergantung pada maksimalisasi kesejahteraaan pemegang saham (shareholder) menjadi tidak relevan lagi, karena keberadaan suatu entitas perusahaan pada dasarnya merupakan kontrak antara perusahaan itu dan berbagai pihak lain (Jensen dan Meckling, 1976).

\section{Teori Legitimasi}

Dowling dan Pfeffer (1976) menyatakan bahwa konsep legitimasi penting dalam menganalisis hubungan antara organisasi dan lingkungannya. Teori legitimasi menjelaskan bahwa organisasi terus berusaha untuk memastikan bahwa mereka beroperasi dalam batas-batas dan norma-norma masyarakat. Batas-batas dan norma-norma ini tidaklah tetap, melainkan berubah sepanjang waktu, sehingga organisasi harus menjadi responsif (Brown dan Deegan, 1998). O'Donovan (2002) menjelaskan teori legitimasi didasarkan pada gagasan bahwa untuk terus dapat beroperasi dengan sukses, perusahaan harus bertindak dalam batas-batas perilaku yang secara sosial dapat diterima oleh masyarakat. Keberadaan suatu perusahaan dalam suatu area karena didukung secara politis dan dijamin oleh regulasi pemerintah serta parlemen yang juga merupakan representasi dari masyarakat (Lako, 2011, hlm. 6).

\section{Pengungkapan Informasi Lingkungan}

Rohman dan Paramitha (2014) mendefinisikan bahwa Pengungkapan informasi lingkungan atau Enviromental Disclosure merupakan perwujudan dari tanggung jawab sosial perusahaan melalui pengungkapan lingkungan pada laporan tahunan, sehingga masyarakat dapat melihat aktivitas dari perusahaan. AlTuwaijri et al. (2004) mendefinisikan bahwa 'environmental disclosure is the disclosure of specific pollution measures and occurrences (toxic waste emissions, oil spills, Superfund sites, etc.) that an investor might find useful in estimating future cash flows'.

\section{Kinerja Lingkungan}

Kinerja lingkungan merupakan hubungan perusahaan dengan lingkungan mengenai dampak lingkungan dari sumber daya yang digunakan, efek lingkungan dari proses organisasi yang dijalankan, implikasi lingkungan atas produk dan jasa, pemulihan pemrosesan produk serta mematuhi peraturan lingkungan kerja (Damanik dan Yadnyana, 2017). Kinerja lingkungan dapat menggambarkan kondisi lingkungan yang baik dan buruk di sekitar perusahaan Irfan dkk. (2018). Kinerja lingkungan merupakan kinerja perusahaan yang berfokus pada kegiatan perusahaan 
dalam melestarikan lingkungan dan mengurangi dampak lingkungan yang timbul akibat aktivitas perusahaan (Rahardjo dan Haryati, 2013).

\section{Kinerja Keuangan}

Kinerja keuangan merupakan salah satu tolak ukur keberhasilan perusahaan dari sisi finansial (Damanik dan Yadnyana, 2017). Menurut Riswan dan Kesuma (2014), Kinerja keuangan merupakan gambaran setiap hasil ekonomi yang mampu di raih oleh perusahaan pada periode tertentu melalui aktivitas-aktivitas perusahaan untuk menghasilkan keuntungan secara efektif dan efisien. Kinerja keuangan perusahaan dapat diukur melalui laporan keuangan yang dikeluarkan secara periodik yang dapat memberikan suatu gambaran tentang posisi keuangan, karena laporan keuangan melaporkan aktivitas yang sudah dilakukan perusahaan dalam suatu periode.

\section{Pengembangan Hipotesis \\ Pengaruh Kinerja Lingkungan terhadap Pengungkapan Informasi Lingkungan}

Teori legitimasi menjelaskan hubungan antara kinerja lingkungan dengan pengungkapan informasi lingkungan, di mana dalam teori tersebut dijelaskan bahwa untuk mempertahankan kelangsungan hidup perusahaan diperlukan legitimasi dari masyarakat, sehingga perusahaan harus menjalankan aktivitasnya sesuai dengan batas dan norma-norma yang ada di masyarkat. Salah satu yang harus diperhatikan oleh perusahaan yaitu mengenai masalah lingkungan. Perusahaan harus memiliki kinerja lingkungan yang baik, dengan terus melakukan upaya-upaya untuk memenuhi tanggung jawab terhadap lingkungan. Ketika kinerja lingkungan perusahaan baik, perusahaan cenderung akan mengungkapkan informasi lingkungannya, sebagai bentuk komunikasi kepada masyarakat dan perusahaan akan memperoleh citra yang positif dari masyarakat. Hal tersebut sesuai dengan penelitian yang dilakukan oleh Ahada dkk.
(2016) yang menjelaskan bahwa perusahaan yang melakukan kegiatan lingkungan dengan baik, akan memiliki dorongan yang kuat untuk melakukan pengungkapan kepada publik..

H1: Kinerja Lingkungan berpengaruh signifikan terhadap Pengungkapan Informasi Lingkungan.

\section{Pengaruh Kinerja Keuangan terhadap Pengungkapan Informasi Lingkungan}

Berdasarkan pada teori stakeholder, untuk mempertahankan eksistensinya, perusahaan memerlukan dukungan dari para stakeholder-nya. Sehingga, di samping bertanggung jawab kepada masyarakat, perusahaan juga harus bertanggung jawab kepada stakeholder lainnya, seperti pemegang saham. Perusahaan harus tetap menjamin kesejahteraan para pemegang saham. Untuk menjamin dan meningkatkan kesejahteraan pemegang saham, perusahaan harus selalu memiliki kinerja keuangan yang baik. Kinerja keuangan merupakan suatu tolak ukur atas kemampuan perusahaan dalam sisi finansial, kinerja keuangan perusahaan dapat dinilai dengan profitabilitas, yang menggambarkan kemampuan perusahaan dalam menghasilkan laba. Dengan memiliki kemampuan yang baik dalam menghasilkan laba, perusahaan cenderung akan melaksanakan tanggung jawab lingkungannya dan mengungkapkan informasi lingkungannya, karena dengan profitabilitas yang tinggi, perusahaan akan mampu mengatasi biaya-biaya yang timbul untuk melaksanakan tanggung jawab lingkungan dan mengungkapkan informasi lingkungannya. Adanya hubungan pengaruh antara kinerja lingkungan terhadap pengungkapan informasi lingkungan juga telah dibuktikan di dalam penelitian Hadjoh dan Sukarta (2013), yang menyatakan bahwa semakin baik tingkat profitabilitas perusahaan, maka akan semakin banyak pengungkapan informasi lingkungan yang dilakukan oleh perusahaan di dalam laporan tahunannya. 
H2: Kinerja Keuangan berpengaruh signifikan terhadap Pengungkapan Informasi Lingkungan.

\section{METODOLOGI PENELITIAN \\ Populasi dan Sampel}

Penelitian ini dilakukan pada perusahaan non keuangan yang terdaftar di Bursa Efek Indonesia (BEI) pada tahun 2015-2017. Teknik analisis data yang digunakan dalam penelitian ini adalah dengan menggunakan analisis regresi linear berganda. Metode yang digunakan untuk pengambilan sampel adalah metode purposive sampling. Berdasarkan pengumpulan data dengan menggunakan metode purposive sampling maka diperoleh 20 perusahaan yang dapat digunakan dalam penelitian ini, sehingga diperoleh jumlah sampel dalam penelitian ini sebanyak 60 sampel. Adapun rincian pemilihan sampel adalah sebagai berikut:

Tabel 1. Rincian Pemilihan Sampel

\begin{tabular}{clc}
\hline No. & \multicolumn{1}{c}{ Keterangan Perusahaan } & Jumlah \\
\hline 1 & $\begin{array}{l}\text { Jumlah Perusahaan Non- } \\
\text { Keuangan yang terdaftar di }\end{array}$ & 470 \\
& Bursa Efek Indonesia & \\
\hline 2 & $\begin{array}{l}\text { Jumlah Perusahaan Non- } \\
\text { Keuangan yang tidak } \\
\text { mempublikasikan Annual Report } \\
\\
\text { tahun 2015-2017 secara berturut- } \\
\text { turut }\end{array}$ \\
\hline 3 & $\begin{array}{l}\text { Perusahaan yang tidak } \\
\text { menerbitkan Sustainability }\end{array}$ \\
& $\begin{array}{l}\text { Report pada tahun 2015-2017 } \\
\text { secara berturut-turut. }\end{array}$ \\
\hline 4 & $\begin{array}{l}\text { Perusahaan yang tidak mengikuti } \\
\text { PROPER oleh Kementerian }\end{array}$ & $(301)$ \\
& $\begin{array}{l}\text { Lingkungan Hidup pada tahun } \\
\text { 2015-2017 secara berturut-turut. }\end{array}$ \\
\hline & $\begin{array}{l}\text { Jumlah Perusahaan yang menjadi } \\
\text { sampel penelitian }\end{array}$ & 20 \\
\hline & Jumlah periode penelitian & 3 \\
\hline & Jumlah sampel penelitian & 60 \\
\hline
\end{tabular}

\section{Pengukuran Variabel}

1. Pengungkapan Informasi Lingkungan $(Y)$

Pengukuran informasi lingkungan dalam penelitian ini menggunakan Indeks GRI versi 4.0 (Global Reporting Initiative versi 4.0), karena GRI ini dibuat untuk memenuhi kebutuhan stakeholder atas sustainability reporting yang terpercaya dan dapat diandalkan, serta dapat digunakan oleh perusahaan dari berbagai ukuran, sektor dan lokasi sehingga digunakan secara luas di seluruh dunia).

\section{Pengungkapan Informasi Lingkungan = $\frac{\text { Jumlah Item yang Diungkapkan }}{34}$}

2. Kinerja Lingkungan $\left(X_{1}\right)$

Pengukuran kinerja lingkungan yaitu dengan skala 1 sampai 5 sesuai dengan jenis warna peringkat PROPER yang diperoleh perusahaan. Pengukuran kinerja lingkungan pada penelitian ini menggunakan hasil peringkat PROPER karena PROPER merupakan bentuk upaya secara langsung yang dilakukan oleh Kementrian Lingkungan Hidup Indonesia sehingga kriteria penilaian yang ditetapkan sesuai dalam peraturan perundangundangan yang berlaku, dan penilaian PROPER pun dilaksanakan setiap tahun.

\section{Kinerja Keuangan $\left(X_{2}\right)$}

Pengukuran kinerja keuangan dalam penelitian ini yaitu dengan menggunakan ROA (Return on Asset), dengan rumus sebagai berikut:

$$
R O A=\frac{\text { Laba Bersih }}{\text { Total Aset }} \times 100 \%
$$

\section{Model Regresi}

Model regresi yang digunakan dalam penelitian ini dinyatakan dalam persamaan berikut:

$$
Y=\alpha+\beta_{1} X_{1}+\beta_{2} X_{2}+e
$$

Keterangan:

$$
\begin{array}{lll}
Y & : \text { Pengungkapan Informasi } \\
& \text { Lingkungan } \\
\beta_{1} \beta_{2}: & \text { Koefisien regresi untuk masing- } \\
& \text { masing variabel independen } \\
X_{1} & : \text { Kinerja Lingkungan } \\
X_{2} & : & \text { Kinerja Keuangan } \\
E & : \text { Error }
\end{array}
$$




\section{HASIL PENELITIAN DAN ANALISIS}

Berdasarkan hasil uji regresi linear berganda pada Tabel 2 diketahui model persamaan regresi linear berganda yaitu, sebagai berikut :

$$
\text { PengLing }=0,143+0,108 \text { KinLing }
$$

$$
-0,009 \mathrm{KinKeu}
$$

Tabel 2. Hasil Analisis Regresi Linear Berganda

\begin{tabular}{llrrr}
\hline \multicolumn{2}{l}{ Variabel } & Coefficient & $\mathrm{t}$ & Sig. \\
\hline \multirow{2}{*}{1} & & & \\
\cline { 2 - 5 }$($ Constant $)$ & .143 & 1,179 & .243 \\
\cline { 2 - 4 } & KinLing & .108 & 3,041 & .004 \\
\cline { 2 - 4 } KinKeu & -.009 & $-4,192$ & .000 \\
\hline \multicolumn{2}{l}{ Adj R ${ }^{2}$} & .264 & & \\
\hline
\end{tabular}

Berdasarkan dari Tabel 2, dapat diketahui bahwa nilai Adjusted $R$ square sebesar 0,264 atau sebesar $26,4 \%$. Hal ini menunjukan bahwa variabel pengungkapan informasi lingkungan dapat dijelaskan oleh variabel kinerja lingkungan dan kinerja keuangan sebesar $26,4 \%$ dari $100 \%$, sedangkan sisanya $73,6 \%$ dijelaskan oleh variabel lain di luar variabel yang diteliti dalam penelitian ini.

Dari persamaan regresi di atas dapat diketahui bahwa variabel dependen pada model regresi dalam penelitian ini adalah pengungkapan informasi lingkungan dengan nilai konstanta sebesar 0,143 . Hal ini menunjukkan bahwa jika variabel kinerja lingkungan dan kinerja keuangan dianggap konstanta 0 , maka rata-rata pengungkapan informasi lingkungan nilainya sebesar 0,143 .

Variabel kinerja lingkungan memiliki koefisien 0.108 dan bertanda positif yang menunjukkan bahwa setiap penambahan tingkat peringkat kinerja lingkungan dalam suatu perusahaan sebesar 1, dengan asumsi nilai koefisien variabel tetap, maka terjadi peningkatan pengungkapan informasi lingkungan yang dilakukan sebesar 0.108. Koefisien positif berarti terjadi hubungan positif antara kinerja lingkungan dengan pengungkapan informasi lingkungan, di mana jika semakin tinggi kinerja lingkungan suatu perusahaan, akan menyebabkan penambahan informasi yang diungkapkan dalam laporan yang dipublikasikan oleh perusahaan.

Nilai koefisien regresi variabel kinerja keuangan adalah negatif sebesar 0,009. Menunjukkan pengaruh variabel kinerja keuangan negatif terhadap pengungkapan informasi lingkungan, berarti setiap kinerja keuangan suatu perusahaan mengalami kenaikan sebesar $1 \%$, maka terjadi penurunan informasi lingkungan yang diungkapkan oleh perusahaan sebesar 0,009. Artinya, semakin tinggi kinerja keuangan perusahaan pada tahun sebelumnya, dapat membuat tingkat pengungkapan informasi lingkungan perusahaan pada tahun berjalan akan menurun.

\section{Pengaruh Kinerja Lingkungan Terhadap Pengungkapan Informasi Lingkungan \\ Hasil pengujian hipotesis} berdasarkan hasil uji t (parsial) variabel kinerja lingkungan terhadap pengungkapan informasi lingkungan pada tahun 2015-2017 memiliki nilai signifikansi 0,004 , artinya nilai signifikan $\leq 0,05(0,004 \leq 0,05), \quad$ serta nilai thitung $>$ ttabel $(3,041>2,00247)$, yang menunjukkan bahwa variabel kinerja lingkungan berpengaruh signifikan terhadap pengungkapan informasi lingkungan, dan pada hasil uji regresi liniear berganda, variabel kinerja lingkungan memiliki koefisien positif, yang berarti kinerja lingkungan memiliki pengaruh signifikan positif terhadap pengungkapan informasi lingkungan, dengan demikian, semakin tinggi peringkat kinerja lingkungan suatu perusahaan maka informasi lingkungan yang diungkapkan oleh perusahaan akan meningkat.

Peringkat atas kinerja lingkungan perusahaan menggambarkan seberapa besar upaya-upaya yang dilakukan oleh perusahaan dalam melaksanakan tanggung jawabnya terhadap lingkungan, dan juga menggambarkan kepekaan perusahaan 
terhadap lingkungan, dapat diartikan bahwa perusahaan dengan peringkat kinerja lingkungan yang tinggi merupakan perusahaan yang peka terhadap lingkungan. Perusahaan yang peka terhadap lingkungan akan termotivasi untuk melaporkan aspek lingkungan mereka, serta prestasi yang diraih dengan memperhatikan aspek lingkungan. Berbagai prestasi dan penghargaan yang diterima oleh perusahaan untuk mengelola lingkungan berfungsi sebagai insentif yang baik bagi perusahaan untuk meningkatkan pengungkapan lingkungan mereka.

Hasil penelitian ini sejalan dengan hasil penelitian sebelumnya, yang dilakukan oleh Rahardja dan Pratama (2013) dan Deswanto dan Siregar (2017) . Hasil penelitian tersebut menyatakan bahwa kinerja lingkungan memiliki pengaruh yang signifikan terhadap pengungkapan informasi lingkungan. Hasil penelitian ini juga sesuai dengan dicretionary disclosure theory (Verrecchia, 1983), yang menjelaskan bahwa kinerja lingkungan yang baik akan mendorong perusahaan untuk melakukan pengungkapan informasi lingkungan, karena kinerja lingkungan yang baik tersebut merupakan 'good news', di mana perusahaan menginginkan agar 'good news' tersebut diketahui oleh publik dan para stakeholder-nya.

\section{Pengaruh Kinerja Keuangan Terhadap Pengungkapan Informasi Lingkungan}

Hasil pengujian hipotesis berdasarkan hasil uji t (parsial) variabel kinerja keuangan terhadap pengungkapan informasi lingkungan memiliki nilai signifikansi 0,000 , berarti nilai signifikan $\leq 0,05 \quad(0,000 \leq 0,05)$, serta thitung <-ttabel $(-4,192<-2,00247)$, yang menunjukkan bahwa variabel kinerja keuangan memiliki pengaruh yang signifikan terhadap pengungkapan informasi lingkungan. Pada hasil uji regresi liniear berganda, variabel kinerja keuangan memiliki koefisien negatif, yang berarti kinerja keuangan memiliki pengaruh signifikan negatif terhadap pengungkapan informasi lingkungan. Dengan demikian, semakin tinggi kinerja keuangan suatu perusahaan pada tahun sebelumnya, maka informasi lingkungan yang diungkapkan oleh perusahaan pada tahun berjalan akan menurun, begitu juga sebaliknya.

Kinerja keuangan menggambarkan kemampuan perusahaan dalam meraih hasil ekonomi pada periode tertentu. Pengaruh kinerja keuangan terhadap pengungkapan informasi lingkungan bernilai negatif, atau yang berarti berbanding terbalik, dikarenakan ketika perusahaan memiliki tingkat kinerja keuangan yang tinggi, manajemen menganggap tidak perlu melaporkan halhal yang dapat mengganggu informasi terkait dengan pencapaian perusahaan dibidang keuangan. Selain itu, perusahaan yang telah memiliki kinerja keuangan yang baik akan lebih berorientasi pada kinerja keuangan semata. Perusahaan cenderung akan lebih tertarik untuk memfokuskan pengungkapan informasi keuangan saja, dibandingkan melakukan pengungkapan informasi lingkungan yang sifatnya masih voluntary. Sebaliknya, pada saat tingkat kinerja keuangan rendah, perusahaan berharap agar para pengguna laporan akan membaca "good news" tentang perusahaan, misalnya dalam aspek yang terkait dengan tanggung jawab perusahaan terhadap lingkungan.

Hasil penelitian ini tidak sejalan dengan hasil penelitian yang telah dilakukan oleh Agustami dan Hidayat (2015), di mana hasil penelitian tersebut menyatakan bahwa profitabilitas berpengaruh positif terhadap pengungkapan tanggung jawab sosial perusahaan. Hasil penelitian ini juga tidak sejalan dengan penelitian yang dilakukan oleh Kamil dan Herusetya (2012), yang menyatakan bahwa profitabilitas tidak berpengaruh terhadap pengungkapan corporate social responsibility. 


\section{SIMPULAN}

Penelitian ini dilakukan untuk menguji pengaruh kinerja lingkungan dan kinerja keuangan terhadap pengungkapan informasi lingkungan perusahaan. Penelitian ini menggunakan perusahaan non-keuangan yang terdaftar di Bursa Efek Indonesia (BEI) pada tahun 2015, 2016, dan 2017 secara berturut-turut, dengan total perusahaan yang memenuhi kriteria sampel sebanyak 20 perusahaan.

Setelah melakukan analisis dan pengujian hipotesis mengenai pengaruh kinerja lingkungan dan kinerja keuangan terhadap pengungkapan informasi lingkungan pada 60 sampel yang telah terpilih, dan berdasarkan hasil penelitian yang telah dijelaskan pada bab sebelumnya, maka dapat diambil kesimpulan bahwa kinerja lingkungan memiliki pengaruh yang signifikan terhadap pengungkapan informasi lingkungan. Hal ini dibuktikan dengan hasil uji parsial $t$, yang memperoleh hasil bahwa yaitu kinerja lingkungan mempunyai nilai signifikansi 0,004, berarti nilai signifikan $\leq 0,05(0,004 \leq$ $0,05)$. Dengan demikian, hipotesis yang menyatakan kinerja lingkungan berpengaruh signifikan terhadap pengungkapan informasi lingkungan diterima. Kinerja keuangan pada tahun sebelumnya memiliki pengaruh yang signifikan terhadap pengungkapan informasi lingkungan pada tahun berjalan. Hal ini dibuktikan dengan hasil uji parsial t, yang memperoleh hasil bahwa kinerja keuangan mempunyai nilai signifikansi 0,000 , berarti nilai signifikan $\leq 0,05$ ( $0,000 \leq 0,05$ ). Dengan demikian, hipotesis yang menyatakan kinerja keuangan pada tahun sebelumnya berpengaruh signifikan terhadap pengungkapan informasi lingkungan tahun berjalan diterima.

\section{Rekomendasi}

Berdasarkan dari hasil penelitian, rekomendasi yang harus diperhatikan bagi penelitian selanjutnya yaitu, agar digunakan periode tahun penelitian yang lebih lama agar diperoleh hasil yang lebih detail tentang perusahaan sehingga bisa diketahui apakah aktivitas tanggung jawab lingkungan, serta pengungkapan informasi lingkungan dilakukan oleh suatu perusahaan secara berkesinambungan atau tidak di setiap uahunnya. Selain itu, untuk penelitian selanjutnya, disarankan menggunakan proksi pengukuran lain untuk mengukur variabel-variabel yang ada pada penelitian ini, seperti menggunakan rasio Return on Equity (ROE), Profit Margin on Sales, atau laba per lembar saham sebagai proksi perhitungan profitabilitas untuk variabel kinerja keuangan, sedangkan untuk mengukur pengungkapan informasi lingkungan, dapat menggunakan Indonesian Environmental Reporting Index (IER), agar mengetahui apakah variabel-variabel tersebut memiliki hubungan yang sama jika diukur dengan proksi pengukuran yang lain.

\section{REFERENSI}

1. _ Undang-Undang Republik Indonesia No. 40 Tahun 2007 Tentang Perseroan Terbatas.

2. Agustami, S., Hidayat, S, Pengaruh Profitabilitas dan Kinerja Lingkungan terhadap Pengungkapan Tanggung Jawab Sosial, Jurnal Riset Akuntansi dan Keuangan, Vol. 3, No. 3. Hal. 753$760,2015$.

3. Ahada, M., Purwohedi, U., dan Mardayanti, Y, Pengaruh Environmental Performance dan Komposisi Dewan Komisaris terhadap Environmental Disclosure, Jurnal Ilmiah Wahana Akuntansi, Vol. 11, No. 1. Hal. 1-26, 2016.

4. Al-Tuwaijri, S.A., Christensen, T.E., and Hughes II, K.E, The relations among environmental disclosure, environmental performance, and economic performance: a simultaneous equations approach, Accounting, Organizations and Society, Issue 29, pp. 447-471, 2004.

5. Anggraini, Fr.R, Pengungkapan Informasi Sosial dan Faktor-Faktor 
yang Mempengaruhi Pengungkapan Informasi Sosial dalam Laporan Keuangan Tahunan (Studi Empiris pada Perusahaan-Perusahaan yang terdaftar Bursa Efek Jakarta), Simposium Nasional Akuntansi IX, Padang, 2006.

6. Brown, N., and Deegan, C, The public disclosure of environmental performance information - a dual test of media agenda setting theory and legitimacy theory, Accounting and Business Research, Vol. 29, No.1, pp. 21-41, 1998.

7. Bursa Efek Indonesia, Laporan Keuangan Tahunan, diakses 06 Oktober 2018, dari https://www.idx.co.id/perusahaantercatat/laporan-keuangan-dantahunan/, 2018.

8. Damanik, I Gst., dan Yadnyana, I,K., Pengaruh Kinerja Lingkungan Pada Kinerja Keuangan Dengan Pengungkapan Corporate Social Responsibility Sebagai Variabel Intervening, E-Jurnal Akuntansi Universitas Udayana, Vol. 20.1, hal. 645-673, 2017.

9. Deswanto, R.B., and Siregar, S.V., The Associations Between Environmental Disclosures With Financial Performance, Environmental Performance, and Firm Value, Social Responsibility Journal, Vol. 14 Issue: 1, pp.180-193, 2017.

10. Dowling, J., and Pfeffer, J., Organizational Legitimacy: Social Values And Organizational Behavior, Pacific Sociological Review, Vol. 18, No.1, pp. 122-136, 1976.

11. Freeman, R.E., and Reed, D.L., Stockholders and Stakeholders: A new Perspective on Corporate Governance, California Management Review, Vol. XXV, No.3, Hal. 88-106, 1983.

12. Global Reporting Initiative (GRI), Pedoman Laporan Keberlanjutan (versi GRI-G4). Diakses 13 September 2018 , dari http://www.globalreporting.org, 2013.
13. Gray, R., Kouhy, R., and Lavers, S., Corporate social and environmental reporting A review of the literature and a longitudinal study of UK disclosure, Accounting, Auditing \& Accountability Journal, Vol. 8, No. 2, pp. 47-77, 1995.

14. Hadjoh, R. A., dan Sukarta, I. M., Pengaruh Ukuran Perusahaan, Kinerja Keuangan dan Eksposur Media pada Pengungkapan Informasi Lingkungan, E-Jurnal Akuntansi Universitas Udayana 4.1, Hal. 1-17, 2013.

15. Jensen, M. C. and Meckling, W.H., Theory of the Firm : Managerial Behavior, Agency Costs and Ownership Structure, Journal of Financial Economics', Vol. 3, No.4, pp. 305-360, 1976.

16. Kamil, A. dan Herusetya, A., Pengaruh Karakteristik Perusahaan Terhadap Luas Pengungkapan Kegiatan Corporate Social Responsibility, Media Riset Akuntansi, Vol. 2, No. 1, Hal. 1-17, 2012.

17. Kosasih, D., Greenpeace Rilis Kerusakan Lingkungan Akibat Tambang di Kalimantan Timur, diakses 03 Agustus 2018, dari https://www.greeners.co/berita/greenp eace-rilis-kerusakan-lingkunganakibat-tambang-di-kalimantan-timur/, 2016.

18. Lako, Dekonstruksi CSR dan reformasi paradigma bisnis \& akuntansi. Jakarta: Erlangga, 2011.

19. O'Donovan, G., Environmental Disclosures In The Annual Report: Extending The Applicability And Predictive Power Of Legitimacy Theory, Accounting, Auditing \& Accountability Journal, Vol. 15, Issue: 3, pp. 344-371, 2002.

20. Rahardja dan Pratama, A.G., Pengaruh Good Corporate Governance Dan Kinerja Lingkungan Terhadap Pengungkapan Lingkungan, Diponegoro Journal Of Accounting, Vol. 2, No. 3, Hal. 1-14, 2013. 
21. RahRISWANardjo, S.N. dan Haryati, R., Pengaruh Corporate Social Responsibility, Kinerja Lingkungan, dan Struktur Corporate Governance terhadap Kinerja Keuangan Perusahaan yang terdaftar di Bursa Efek Indonesia, Diponegoro Journal of Accounting, Vol. 2, No. 2, Hal. 1-15, 2013.

22. Riski, P., Pencemaran Udara Pabrik Semen Diduga Sebabkan Kematian Warga?. Mongabay, diakses pada 03 Agustus 2018, dari http://www.mongabay.co.id/2016/04/2 6/pencemaran-udara-pabrik-semendiduga-sebabkan-kematianwarga/,2016.

23. Riswan dan Kesuma, Y.F., Analisis Laporan Keuangan Sebagai Dasar Dalam Penilaian Kinerja Keuangan PT. Budi Satria Wahana Motor, Jurnal Akuntansi \& Keuangan, Vol. 5, No. 1. Hal. 93-121, 2014.

24. Rohman, A. dan Paramitha, B.W., Pengaruh Karakteristik Perusahaan Terhadap Enviromental Disclosure, Diponegoro Journal Of Accounting, Vol. 3, No. 3, Hal. 1-11, 2014.

25. Suripatty, C.A., Viral di Medsos, Fotofoto Perairan di Raja Ampat Diduga Tercemar Limbah Tambang, Sindonews, diakses 03 Agustus 2018, dari

https://daerah.sindonews.com/read/13 03837/174/viral-di-medsos-foto-fotoperairan-di-raja-ampat-didugatercemar-limbah-tambang1525703444, 2018.

26. Verrechia, R. E., Discretionary Disclosure, Journal of Accounting and Economics, pp. 179-194, 1983.

27. Wartaekonomi, 21 Perusahaan Masuk Peringkat Hitam Penilaian Proper, diakses 03 Agustus 2018, dari https://www.wartaekonomi.co.id/read $\underline{\text { 80821/21-perusahaan-masuk- }}$ peringkat-hitam-penilaianproper.html, 2015.

28. Wijaya, Maria, Faktor-Faktor yang Mempengaruhi Pengungkapan
Tanggung Jawab Sosial Pada Perusahaan Manufaktur yang Terdaftar Di Bursa Efek Indonesia, Jurnal Ilmiah Mahasiswa Akuntansi, Vol 1, No. 1, Hal. 26-30, 2012.

29. Warotikan, E.J., Topowijono, dan Sulasmiyati, S., Analisa Pengaruh Ukuran Perusahaan, ROA dan DER terhadap Pengungkapan Tanggung Jawab Sosial Perusahaan, Jurnal Administrasi Bisnis (JAB), Vol. 26, No. 2, Hal. 1-6, 2015.

30. Zulfikar, R., Badina, T., dan Arum, M.S., Corporate Governance, Environmental Disclosure, dan Kepemilikan Keluarga, Jurnal Akuntansi. Vol. 3, No. 2, Hal. 1-13, 2016. 